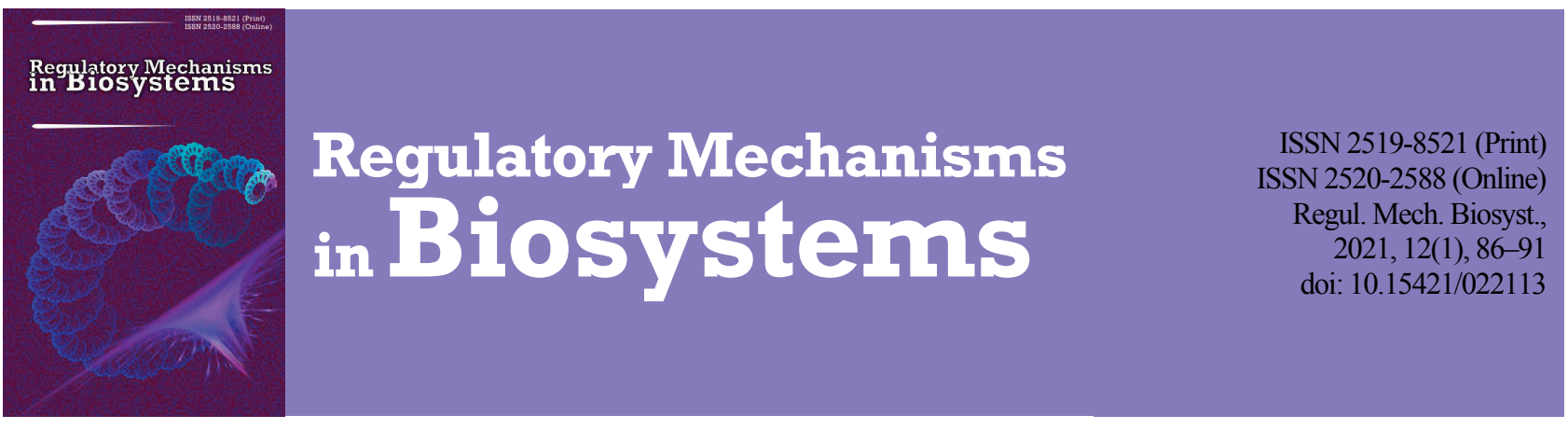

\title{
Safety of livestock products of bulls on various diets during fattening in the conditions of radioactive contamination
}

\author{
I. Savchuk*, O. Skydan**, V. Stepanenko**, M. Kryvyi**, S. Kovalova*** \\ *Institute for Agriculture of Polissia NAAS, Zhytomyr, Ukraine \\ **Polissia National University, Zhytomyr, Ukraine \\ ***Zhytomyr Branch of the State Institution «Institute of Soil Protection of Ukraine», Zhytomyr, Ukraine
}

\begin{abstract}
Article info
Received 11.02.2021

Received in revised form

Savchuk, I., Skydan, O., Stepanenko, V., Kryvyi, M., \& Kovalova, S. (2021). Safety of livestock products of bulls on various diets doi:10.15421/022113
\end{abstract} 05.03 .2021

Accepted 06.03.2021

Institute for Agriculture

of Polissia NAAS,

Kyivske highway, 131,

Zhytomyr, 10007, Ukraine.

Tel.: +38-097-875-49-27.

E-mail:isavchuk.zt@ukr.net

Polissia National University,

Staryi boulevard, 7,

Zhytomyr, 10008, Ukraine.

Tel.: +38-067-394-38-60.

E-mail:kryvyiznau@gmail.com

Zhytomyr branch of the

State Institution "Institute

of Soil Protection of Ukraine",

Peace Averue, 21A,

Zhytomyr, 10020, Ukraine.

E-mail:

inna.yashchuk.9224@gmail.com

Production of high-quality and safe food products in the conditions of technogenic environmental pollution is a problem worldwide, especially in Ukraine. As a result of the disaster at the Chornobyl Atomic Power Plant, radioactive substances, including caesium137, contaminated the soil not only in Ukraine, but in many other countries. Zhytomyr Oblast is the fifth largest oblast in Ukraine and one of the regions that were the most damaged by the accident. Furthermore, this territory is contaminated by the most toxic heavy metals - lead $(\mathrm{Pb})$ and cadmium $(\mathrm{Cd})$ that actively migrate in the biological system: soil $\rightarrow$ plant $\rightarrow$ animal $\rightarrow$ production $\rightarrow$ human, intensely accumulating in the products of plant and animal origin. The complex ecological situation and broad spectrum of biological and toxic actions of ${ }^{137} \mathrm{Cs}, \mathrm{Pb}, \mathrm{Cd}$ require a number of measures that would prevent transformation of radioactive elements and heavy metals in the organism of animals, increase animals ' productivity and safety of the food products made in the conditions of the Ukrainian Polisia. Therefore, we aimed at substantiating the practicability of using silage-concentrate, silage-concentrate-root vegetable and silage-concentrate-hay types of diet for young cattle during fattening and determining the impact of accumulation of ${ }^{137} \mathrm{Cs}$, $\mathrm{Pb}$ and $\mathrm{Cd}$ in livestock products. To perform the studies, we formed three groups of young bulls of Ukrainian Black Pied cattle using the method of analogues with creating comfortable maintenance condition and organization of in-detail planned feeding. The diet was composed of fodders prepared in the conditions of radioactive contamination. The laboratory surveys indicated that the main sources of ${ }^{137} \mathrm{Cs}$ ingress in the organism of the animals were roughages and various types of silages, and the sources of heavy metals $\mathrm{Pb}$ and $\mathrm{Cd}$ were hay of red clover and concentrated fodders. In the experimental studies, we determined absolute and average daily weight gains, expenditures of metabolic energy per $1 \mathrm{~kg}$ of weight increment, specific activity of ${ }^{137} \mathrm{Cs}$ and concentrations of the heavy metals $(\mathrm{Pb}$ and $\mathrm{Cd})$ in the biological system "fodder-animal-production" during feeding of bulls with various-type diets in the conditions of the III zone of radioactive pollution. It was confirmed that substituting maize silage and carbohydrate fodders increased the average daily gains in the live weight by $2.3-4.6 \%$, decreased specific activity of ${ }^{137} \mathrm{Cs}$ by $8.7-20.1 \%$, the content of $\mathrm{Pb}$ by $36.2 \%$, Cd by $34.1-66.7 \%$ in the longissimus at silage-concentrate-root vegetable and silage-concentrate-hay types of diet for bulls. Thus, use of silage-concentrate-root vegetable and silage-concentrate-hay types of diets compared with silage-concentrate feeding had a positive effect on their productivity and safety of the food production.

Keywords: feeding; fodders; transfer coefficients; caesium-137; lead; cadmium; meat; liver.

\section{Introduction}

Environmental pollution has a significant impact on the physiological condition of the organism, productivity and safety of products of livestock, which comprise a link in the food chain of humans. Accumulation of ${ }^{137} \mathrm{Cs}$ and heavy metals in the tissues of the organism leads to chronic diseases and directly affects the health condition of the population. Thus, study of the action of toxic elements of technogenic origin in the content of soil, natural, cultivated phytocenoses and in the organisms of animals and humans is a relevant global ecological problem.

As a result of the Chornobyl disaster, large areas of natural and cultivated lands in the Polesia zone became contaminated with radioactive elements and heavy metals (Hatch et al., 2005; Romanchuk et al., 2017). The results of monitoring (Romanchuk et al., 2017) indicate that contents of caesium- 137 in soil on grazing sites and hay fields account for 0.66 and $1.26 \mathrm{Ci} / \mathrm{km}^{2}$. The highest content of this element - within 1.23$5.79 \mathrm{Ci} / \mathrm{km}^{2}$ - was recorded in the lands of Olevsk, Ovruch, Korosten, Luhyny and Narodychi districts. Soil-climatic conditions of Polesia are light according to the granulometric composition, soils are turf-podzolized with average thickness of the humus horizon equaling $24-26 \mathrm{~cm}$, having low content of metabolic bases and acidic $\mathrm{pH}$. These conditions are favourable for the migrations of ${ }^{137} \mathrm{Cs}, \mathrm{Pb}, \mathrm{Cd}$. Moreover, according to the study (Salt et al., 1992), higher digestibility of nutritious fodders in summer than in winter leads to high absorption of radio caesium in the gastrointestinal tract, resulting in its higher concentration in the muscles (Summerling, 1984).

Lead $(\mathrm{Pb})$, according to the data (Burki, 2012), is an especially dangerous toxicant among heavy metals. It damages almost all the systems of the organism: hematopoietic, digestive, urine-removing, cardio-vascular, endocrine systems, causes malfunctioning of metabolic processes, central and peripheral nervous systems, damages cellular membranes and cellular metabolism (Jadhav \& Sarkar, 2007). Production of lead increases globally and therefore its anthropogenic ingress greatly exceeds the natural one (Patrick, 2006). The results of the studies (Patra et al., 2011) revealed that impact of lead causes changes in the acid-base homeostasis in the organism, which further affects the migration of the metal. 
Cadmium $(\mathrm{Cd})$ is a metal that is broadly distributed in various ecosystems, not only in the zone of radioactive pollution (Patra et al., 2006; Yu et al., 2006), but also in soil, and ore, where it is bound with zinc (Yu et al., 2006). This metal is a mutagen and carcinogen that poses a potential genetic threat and is extremely toxic (Newairy et al., 2007; Swarup et al., 2007; Stanevičine et al., 2008); and is not necessary for the organisms of animals and humans (El-Sharaky et al., 2007; Djuić-Ćosić et al., 2008). It is introduced into the environment by volcanic eruptions and is released from plants. Nonetheless, the main source of cadmium is anthropogenic (Stanevičine et al., 2008). Chronic intoxication with cadmium impairs the metabolism of calcium in the bone marrow, causes anemia, has a toxic impact on the activity of the central nervous, cardio-vascular, reproductive, support-locomotion systems (Rodríguez et al., 2001; Uetani et al., 2005).

Such a condition of the environment and toxic effects of ${ }^{137} \mathrm{Cs}$ and heavy metals significantly influence the development of the sphere of livestock in the region, for the preparations of fodders in the zone of contamination and feeding them to agricultural animals negatively affect the metabolic substances, reduce resistance of the organism and result in production of harmful products of animal origin (Howard \& Mayes, 1989).

\section{Materials and methods}

Experimental studies were performed in compliance with the humane, ethical and moral and legal principles of treating animals. The maintenance conditions of the animals corresponded to their biological, speciesrelated and individual specifics and the animals' natural needs for food, water, sleep, and movement were satisfied. The place where the young experimental animals were kept had sufficient space, the required temperature regime, light, ventilation and possibility of contact with their natural environment. The methods, conditions of the studies were approved by the Ethics Committee on Issues Related to Treatment of Animals used in Scientific Research.

Scientific agricultural experiments were conducted on Ukrainian Pied bulls in a section of the physiological yard of the Institute of Agriculture of Polisia of the National Academy of Sciences. According to the analogue group technique, we formed three groups of bulls with 8 individuals in each: the I group (control) received the diet of silage-concentrate type; the II type (experimental) - silage-concentrate-root vegetable; the III group (experimental) - silage-concentrate-hay diet. While composing the experimental groups, we took into account live weight, age, physiological condition and mean daily weight gains of the animals in the experimental period. During the experiments, the animals were in the conditions of tethered maintenance and fed twice a day. Mean live weight of young cattle at the beginning of the experiment ranged 267.6-276.2 kg. The preparation and the main periods lasted respectively 32 and 148 days. To feed the bulls, we used fodders prepared by us. To determine contents of ${ }^{137} \mathrm{Cs}, \mathrm{Pb}$ and $\mathrm{Cd}$, we selected medium samples of roughages, juicy and concentrated fodders. The crops for preparation of silage, root vegetables and seeds were grown on agricultural land where the level of soil contamination was more than $5 \mathrm{Ci} / \mathrm{km}^{2}$. The animals had free access to water containing an undetermined level of radioactive elements and heavy metals.

According to the scheme of the experiment, during the preparation and the main periods, young bulls of the I group received the diet of silage-concentrate type, in which maize silage and red clover silage comprised $54.7 \%$ of nutritional value, concentrated $-36.6 \%$ and roughages $8.7 \%$. Bulls of the II and III groups, throughout the preparation period, similarly to the animals of the control group, consumed the same food and in the same amount. In the main period, the diet of young bulls of the II group was substituted with $20 \%$ silage fodders, fodder and sugar beets, and the animals of the III group received a decreased specific weight of maize silage and increased amount of roughages and root vegetables.

The composition of the diets was as follows: the II group: roughages $-8.9 \%$, maize silage and red clover silage $-34.8 \%$, fodder beet and sugar beet $-20.3 \%$, concentrates $-36.0 \%$; III group: roughages $-13.5 \%$, maize silage and red clover silage $-42.3 \%$, fodder beet $-8.9 \%$, concentrates $-35.3 \%$. Diets for the animals were calculated based on actual chemical content of fodders according to the detailed parameters of nutritional value to obtain mean daily increments of $1,000-1,200 \mathrm{~g}$. The amount of metabolic energy in the diets of the I, II and the III groups on ave- rage was $95.7 \mathrm{MJ}$ with dry matter content of $10.5 \mathrm{~kg}$. At the same time, the diets of the control group were unbalanced according to the sugar content. The sugar-protein proportion in the diets of the group was notably different, equaling 0.42:1 in the I group, 1.38:1 in the II group, and 1.07:1 in the III group. During the period of the experiment, concentration of metabolic energy in $1 \mathrm{~kg}$ of dry matter of young cattle, both the control and experimental, equaled $9.1 \mathrm{MJ}$.

After the scientific-agricultural experiment, we performed control slaughter of animals in the workshop of the Korostensky Meat Plant, three animals from each of the group, and extracted samples of the longissimus weighing $400 \mathrm{~g}$ from between the 9th and the 12th right ribs of the half carcass and the liver. Specific activity of ${ }^{137} \mathrm{Cs}$ in fodders and products of livestock were determined on SEG spectrometer -0.5 . The samples of plant and animal origin for determining contents of lead, cadmium in them were prepared using the method of dry mineralization on an atomicabsorptive spectrometer Kvant-2A(DSTU 7670:2014).

Transfer coefficients (TC) of ${ }^{137} \mathrm{Cs}, \mathrm{Pb}$ and $\mathrm{Cd}$ from the fodders to the longissimus and the liver were calculated using the formula: $\mathrm{TC}=$ level of ${ }^{137} \mathrm{Cs}, \mathrm{Pb}$ and $\mathrm{Cd}$ in the products of animals, $\mathrm{Bq} / \mathrm{kg}, \mathrm{mg} / \mathrm{kg}$; ingress of ${ }^{137} \mathrm{Cs}, \mathrm{Pb}$ and $\mathrm{Cd}$ to the organism with daily diet, $\mathrm{Bq} / \mathrm{kg}, \mathrm{mg} / \mathrm{kg}$ (Hashimoto et al., 2011; Manabe et al., 2014). The obtained results are presented as mean value \pm standard error $(x \pm S E)$. The differences of the mean concentrations of the heavy metals and ${ }^{137} \mathrm{Cs}$ between the groups were analyzed using the ANOVA test and Bonferroni correction.

\section{Results}

The main parameters that characterize the productivity of the experimental animals are increments in their live weight. During the experiments, we determined that substitution of $12.4-20.0 \%$ silage with roughage and carbohydrate fodders in the diets of the young bulls had no significant effect on live weight of the animals of the experimental groups, while the difference between the absolute increments was within 3.7-7.8 with greater weight gain in animals of the experimental group.

\section{Table 1}

Live weight increment of the bulls and their expenditures of energy for $1 \mathrm{~kg}$ of increment for the period of studies $(n=8, x \pm S E)$

\begin{tabular}{lccc}
\hline \multirow{1}{*}{ Parameters } & \multicolumn{3}{c}{ Group } \\
\cline { 2 - 4 } & $\begin{array}{c}\mathrm{I}- \\
\text { control }\end{array}$ & $\begin{array}{c}\text { II }- \\
\text { experimental }\end{array}$ & $\begin{array}{c}\text { III- } \\
\text { experimental }\end{array}$ \\
\hline $\begin{array}{l}\text { Live weight of one individual at the } \\
\text { beginning of the experiment, } \mathrm{kg}\end{array}$ & $276.2 \pm 4.4$ & $270.1 \pm 6.0$ & $267.6 \pm 6.1$ \\
$\begin{array}{l}\text { Live weight of one individual at the end } \\
\text { of the experiment, } \mathrm{kg}\end{array}$ & $439.6 \pm 13.2$ & $441.3 \pm 10.7$ & $434.7 \pm 8.3$ \\
$\begin{array}{l}\text { Absolute increment of live weight, } \mathrm{kg} \\
\text { Mean daily increment, g }\end{array}$ & $163.4 \pm 9.6$ & $171.2 \pm 10.3$ & $167.1 \pm 9.7$ \\
$\begin{array}{l}\text { Expenditures of metabolic energy for 1 } \\
\text { kg of live weight increment, MJ }\end{array}$ & $1104 \pm 45$ & $1157 \pm 41$ & $1129 \pm 42$ \\
\hline
\end{tabular}

Note: inter-group difference is statistically insignificant (ANOVA test with Bonferroni correction).

The greatest mean daily increments in live weight were seen in the bulls fed with diets of silage-concentrate-root vegetable and silage-concentrate-hay types. According to this parameter, they exceeded the control analogues by $2.3-4.6 \%$, having insignificant difference. Different intensity of growth of experimental bulls, at different types of feeding, positively influenced the expenditures of metabolic energy per unit of increment of live weight. Particularly, bulls of the experimental group expended 2.7$3.4 \%$ less metabolic energy per $1 \mathrm{~kg}$ of increment than the control animals.

According to the animals' average daily intake of fodders and the content of ${ }^{137} \mathrm{Cs}$ in them (Fig. 1), we calculated mean daily ingress of this element into the organism of the fattened bulls. In the I group, it equaled 1454.1 Bq/day, which was 7.4 Bq/day less than in the second one and $112.9 \mathrm{~Bq} /$ day less than in the third. In the process of the studies, we found the main pathways of ${ }^{137} \mathrm{Cs}$ introduction into the organism of animals. The lowest level of radioactive caesium in the fodders for the young cattle was $32.3 \mathrm{~Bq} / \mathrm{kg}$, while the highest was $151.5 \mathrm{~Bq} / \mathrm{kg}$. The highest content of this element was found in panic grass straw and red clover hay. To prepare hay, we used the method of natural drying. The green mass of red clover for preparation of hay was sown in the flower-budding phase 
and the beginning of bloom, at the height of 10-12 $\mathrm{cm}$ above the ground. Roughages contained $82.5 \%$ of dry matter.

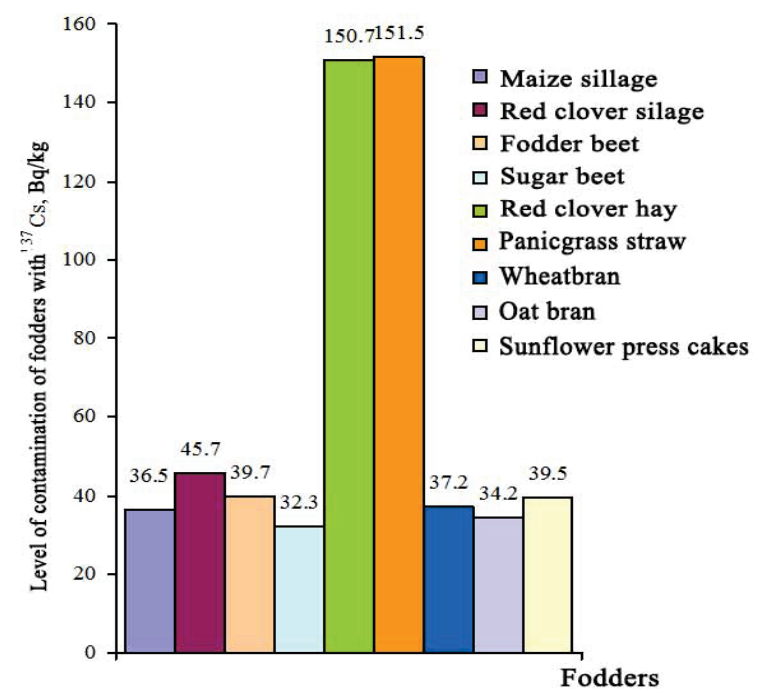

Fig. 1. Content of ${ }^{137} \mathrm{Cs}$ in roughages, juicy and concentrated fodders

The mass of maize and red clover silages was greater than such of other fodders in the diets of the bulls, and the content of ${ }^{137} \mathrm{Cs}$ in them was found to be $41.1 \mathrm{~Bq} / \mathrm{kg}$ on average. Laboratory studies revealed that the contents of dairy and acetic acids accounted for $53.9 \%$ and $46.1 \%$ respectively. The least radioactively contaminated products were sugar beets and bran of cereals. Observation of behaviour of bulls fed with radioactively contaminated fodders in the preparation and the main periods of observations revealed no abnormal symptoms in any of the animals. During the studies, we determined insignificant inter-group difference between ${ }^{137} \mathrm{Cs}$ concentration in the products of slaughtered experimental animals depending on the food factor (Table 2).

The results of the assessments revealed that specific activities of ${ }^{137} \mathrm{Cs}$ in the longissimus and the liver of the bulls of all the experimental groups were within the limits of 26.6 to $33.3 \mathrm{~Bq} / \mathrm{kg}$ and $28.3-28.6 \mathrm{~Bq} / \mathrm{kg}$ respectively, which is much lower than the ones approved in the Ukrainian National Hygienic Normative Acts of the allowable levels (AL) of the content of radionuclides in the food products (AL approved in 2006 is $200 \mathrm{~Bq} / \mathrm{kg}$ ). At the same time, in the animals that consumed the diets of silage-concentrate-root vegetable and silage-concentrate-hay types, the concentration of ${ }^{137} \mathrm{Cs}$ was $8.7-20.1 \%$ lower in the muscle tissues, and
$0.4-1.0 \%$ lower in the liver than after feeding the young animals with silage-concentrate diet. Transfer coefficients of ${ }^{137} \mathrm{Cs}$ into the longissimus and the liver of the experimental bulls ranged $1.4-2.3 \%$ and $1.8-2.0 \%$ respectively. The greatest transfer of ${ }^{137} \mathrm{Cs}$ into the products was seen in the young cattle of the I (control) group, equaling within 2.0-2.3\% (Fig. 2).

Table 2

Content of ${ }^{137} \mathrm{Cs}$ in products of slaughtered bulls $(n=3, x \pm S E$ )

\begin{tabular}{lccc}
\hline \multirow{1}{*}{ Parameters } & \multicolumn{3}{c}{ Group } \\
\cline { 2 - 4 } & $\begin{array}{c}\mathrm{I}- \\
\text { control }\end{array}$ & $\begin{array}{c}\mathrm{II}- \\
\text { experimental }\end{array}$ & $\begin{array}{c}\mathrm{III}- \\
\text { experimental }\end{array}$ \\
\hline Content of ${ }^{137} \mathrm{Cs}$ in the diet, Bq/day & 1454.1 & 1461.5 & 1567.0 \\
Content of ${ }^{137} \mathrm{Cs}$ in the longissimus, & $33.3 \pm 3.5$ & $26.6 \pm 2.7^{*}$ & $30.4 \pm 2.6^{*}$ \\
Bqkg & $28.6 \pm 1.9$ & $28.3 \pm 1.5^{*}$ & $28.5 \pm 2.4^{*}$ \\
Content of ${ }^{137} \mathrm{Cs}$ in the liver, Bq/kg & & &
\end{tabular}

Note: see Table 1.

$\square$ I control group (silage-concentrate diet)

$\square$ II group (silage-concentrate-root vegetable diet)

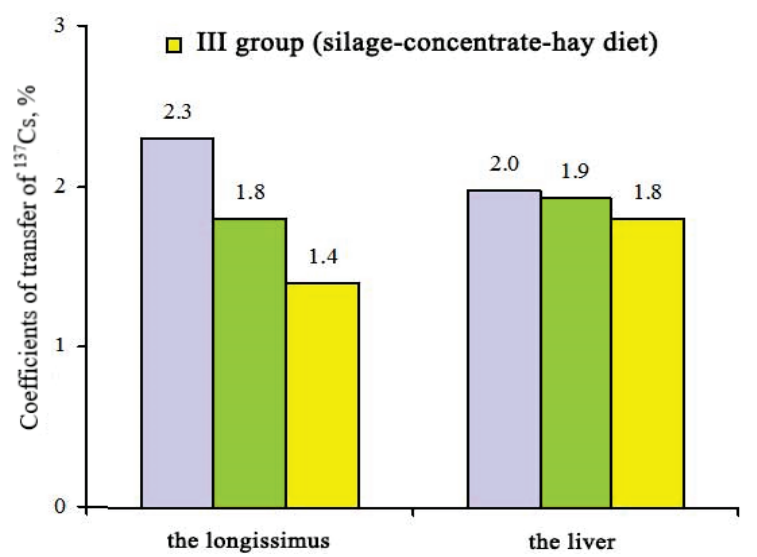

Fig. 2. Transfer coefficients of ${ }^{137} \mathrm{Cs}$ to the longissimus and the liver of the experimental bulls

The level of heavy metals (Fig. 3) in some fodders exceeded the maximum allowable content (MAC) determined by the decree of the Ministry of Agrarian Policy and Food Supply of Ukraine "List of maximum allowable levels of undesired substances in fodders and food substrates for animals" (2017).

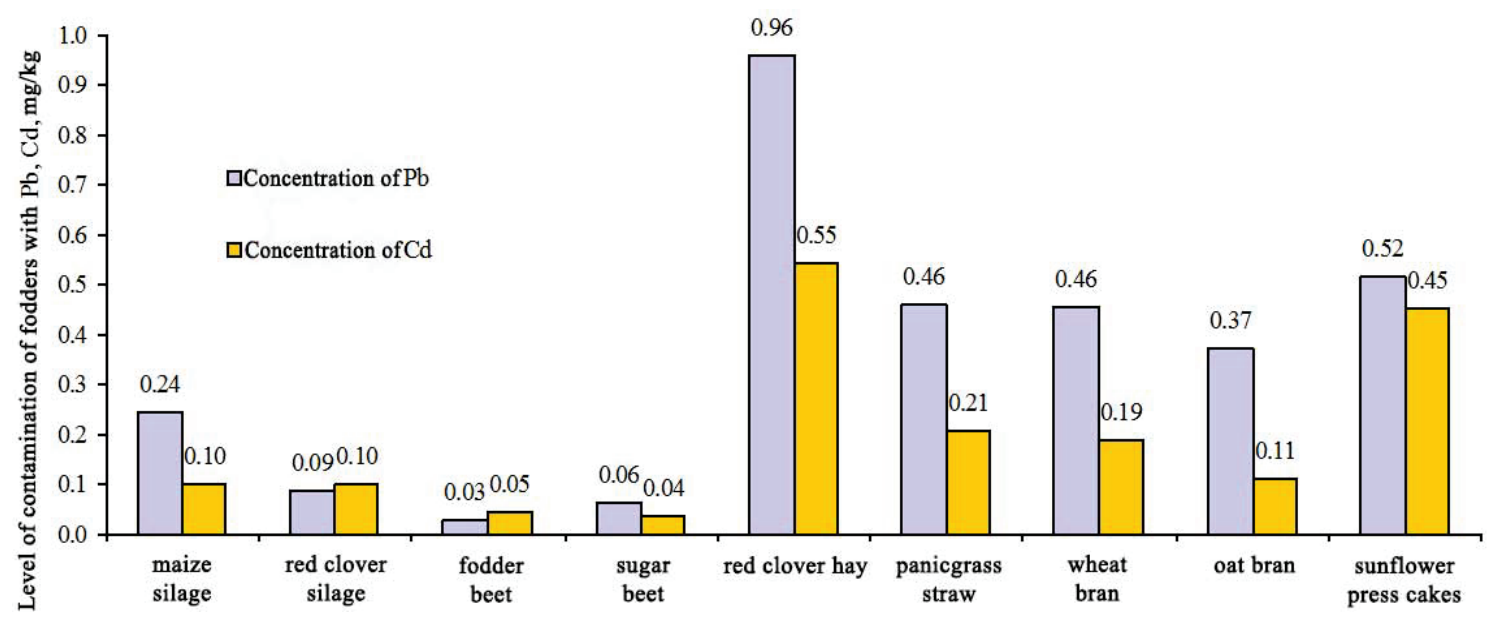

Fig. 3. Content of $\mathrm{Pb}$ and $\mathrm{Cd}$ in roughages, juicy and concentrated fodders $(\mathrm{mg} / \mathrm{kg})$

The studies determined a 1.5 -fold excessive content of cadmium in sunflower press cakes and 1.8-fold excess in red clover hay. However, its level was lowest in silage and fodder beets, sugar beets and oat bran. The level of $\mathrm{Pb}$ contamination in roughages, juicy and concentrated fodders did not exceed the maximum allowable content. Nonetheless, the greatest amount of this element was found in red clover hay, sunflower press cakes, panic grass straw, sunflower and oat bran. To feed the experimental animals, we used various types of diet with concentrations of $\mathrm{Pb}$ ranging 6.401-7.940 mg/day (Table 3). According to the adopted State Sanitary Rules and Norms of Ukraine "Maximum allowable levels of separate substances in food products" (2020), the maximum allowable level (MAL) of lead is $0.10 \mathrm{mg} / \mathrm{kg}$ in meat, $0.5 \mathrm{mg} / \mathrm{kg}$ in the liver, and MAL of 
cadmium is respectively 0.050 and $0.50 \mathrm{mg} / \mathrm{kg}$. The results of the assessments revealed that the accumulation of $\mathrm{Pb}$ was lower than MAL $(0.10$ $\mathrm{mg} / \mathrm{kg}$ ) only in the longissimus of the bulls of the II experimental groups. However, the concentration of this heavy metal in beef from the young cattle of the II group significantly decreased by $36.2 \%$, whereas in the III group, this parameter unreliably increased by $6.7 \%$ compared with the analogues of the I group. Content of lead in the liver of animals of all the groups 1.5-1.9 times exceeded the maximum allowable level. Nonetheless, feeding the cattle diets of silage-concentrate-hay type led to $18.9 \%$ decrease in the $\mathrm{Pb}$ concentration in the liver compared with silageconcentrate feeding. The lowest transfer of this element into the meat was in animals of the II group, though $3.4 \%$ more $\mathrm{Pb}$ was introduced into the liver of animals of this group than in those of the I group and $4.8 \%$ more than in those of the III group (Fig. 4)

Table 3

Concentration of $\mathrm{Pb}, \mathrm{Cd}$ in diets and products of slaughtered bulls $(\mathrm{n}=3, \mathrm{x} \pm \mathrm{SE})$

\begin{tabular}{|c|c|c|c|}
\hline \multirow[b]{2}{*}{ Parameters } & \multicolumn{3}{|c|}{ Group } \\
\hline & $\begin{array}{c}\mathrm{I}- \\
\text { control }\end{array}$ & $\begin{array}{c}\text { II }- \\
\text { experimental }\end{array}$ & $\begin{array}{c}\text { III- } \\
\text { experimental }\end{array}$ \\
\hline Content of $\mathrm{Pb}$ in the diet, 1 & 7.940 & 6.401 & 7.342 \\
\hline $\begin{array}{l}\text { Content of } \mathrm{Pb} \text { in the longissimus, } \\
\mathrm{mg} / \mathrm{kg}\end{array}$ & $5 \pm 0.026$ & $0.067 \pm 0.024^{*}$ & $0.112=$ \\
\hline Content of $\mathrm{Pb}$ in the liver, $\mathrm{mg} / \mathrm{kg}$ & $0.901 \pm 0.192$ & $0.945 \pm 0.155$ & $0.731 \pm 0.215$ \\
\hline Content of Cd in the diet, mg/day & 3.909 & 3.535 & 3.593 \\
\hline $\begin{array}{l}\text { Content of Cd in the longissimus, } \\
\mathrm{mg} / \mathrm{kg}\end{array}$ & $0.255 \pm 0.018$ & $0.168 \pm 0.008^{*}$ & 0.085 \\
\hline Content of Cd in the liver, $\mathrm{mg} / \mathrm{kg}$ & $0.118 \pm 0.016$ & $0.063 \pm 0.052 *$ & $0.100 \pm 0.065$ \\
\hline
\end{tabular}

Note: $*-\mathrm{P}<0.05$ inter-group difference is statistically significant (ANOVA test with Bonferroni correction)

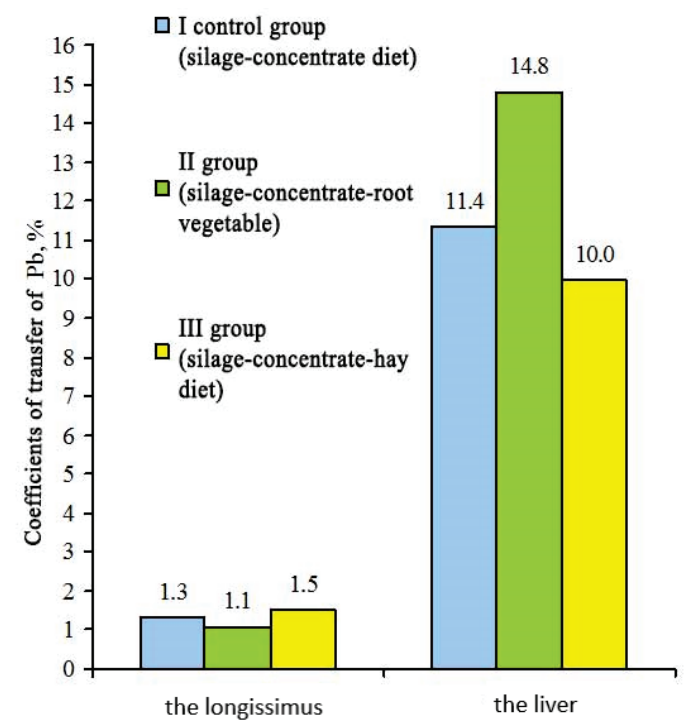

Fig. 4. Transfer coefficients of $\mathrm{Pb}$ to the longissimus and the liver of the experimental bulls

Intake of silage and concentrated fodders increased the ingress of cadmium by $0.374 \mathrm{mg} /$ day in animals of the I group compared with the II group and $0.316 \mathrm{mg} /$ day compared with the III group (Table 3). Our studies revealed that $\mathrm{Cd}$ concentration in the longissimus of the fattened animals of all the experimental groups was 1.7-5.1 times higher than the MAL. At the same time, the bulls that consumed silage-concentrate-root vegetable and silage-concentrate-hay diets (II and III groups), compared with silage-concentrate diet (I group), were observed to have Cd accumulation in the muscle tissue lower by $0.087-0.170 \mathrm{mg} / \mathrm{kg}$, or by $34.1-$ $66.7 \%$ at significant inter-group difference. The highest content of $\mathrm{Cd}$ in the liver was in the experimental young bulls of the control group, equaling $0.118 \mathrm{mg} / \mathrm{kg}$, which did not exceed the normative values. For the animals fed with silage-concentrate-root vegetable type of diet, the concentration of $\mathrm{Cd}$ in the liver, compared with the I group, decreased by $0.055 \mathrm{mg} / \mathrm{kg}$ or $46.6 \%$. Feeding bulls with silage-concentrate-hay diets did not significantly affect the $\mathrm{Cd}$ concentration in the liver compared with the control.

Coefficients of transfer of $\mathrm{Cd}$ with food of the diet into the longissimus varied broadly. However, it was the highest in the animals of the I group $-6.5 \%$, whereas much lower coefficients were seen in the II and the III groups (Fig. 5).

$\square$ I control group (silage-concentrate diet)

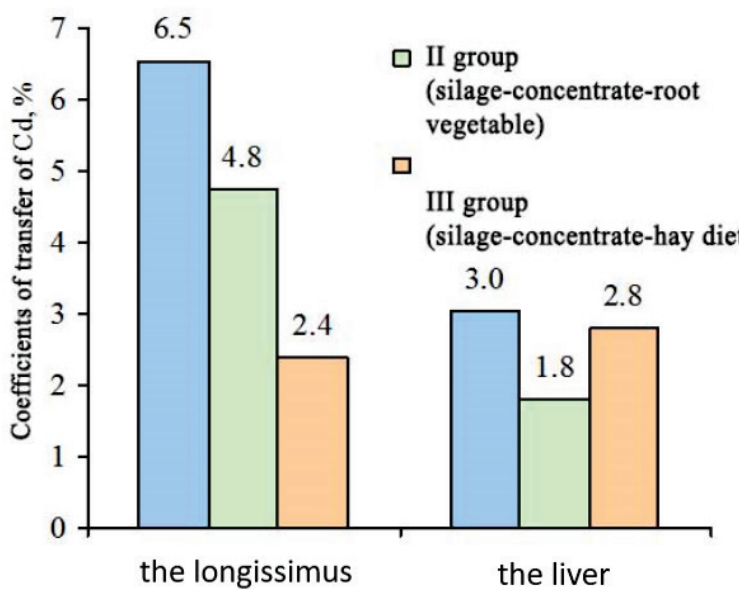

Fig. 5. Transfer coefficients of $\mathrm{Cd}$ to the longissimus and the liver of the experimental bulls

Consumption of silage-concentrate-root vegetable diets reduced the transfer coefficient of $\mathrm{Cd}$ into the liver by $1.2 \%$, and silage-concentratehay-by $0.2 \%$, compared with silage-concentrate diet.

\section{Discussion}

The main task during the production of beef in territories polluted with radionuclides is providing animals with "purest" food possible and reducing the transfer coefficients of ${ }^{137} \mathrm{Cs}, \mathrm{Pb}$ and $\mathrm{Cd}$ into the products. Unfortunately, it is not always possible. In our opinion, introduction of measures for reducing the content of radionuclides and heavy metals in fodders, as well as introducing changes in the structure of diets for the animals, adding supplements to their diets, which provide detailed feeding, would prevent the transfer of these harmful substances into meat and the liver.

Heavy metals such as $\mathrm{Pb}, \mathrm{Cd}$ and radioactive caesium-137 are toxic compounds that significantly affect the parameters of quality, safety of fodders for animals of various species. Intake of ecologically clean foods is not only essential to the health of the animals, but is an important factor that can reduce the impact of toxic compounds on the organism of humans. Accumulation of those substances in the organs of animals is a complex ecological problem (Hayama et al., 2013) that first of all depends on the concentration of the substances in fodders and duration of intake of contaminated food. Other factors such as sex, age and weight of the animals are insignificant (Kan \& Meijer, 2007).

The results of the study (Beresford \& Howard, 2011) confirm that the main path of introduction of radionuclides to the organism of animals after the nuclear incident is intake of polluted foods, whereas breathing of air and water intake were most significant to the animals at the early stage of the nuclear accident (Steinhauser, 2017). Moreover, the studies (Pichtel \& Kuroiwa, 2000) revealed that the chemical elements lead and cadmium and their compounds are the most toxic and they do not decompose in soil and water (Kozak \& Brygadyrenko, 2018), and migrate through the trophic chain, causing negative changes in the organisms of both people and animals (Muller \& Manfred, 1994). Once in the organism of animals, lead accumulates in the liver, kidneys, brain and bones (Foster, 1992). Its halflife is around two months in blood, and up to 20-30 years in bones (Howard et al., 2001). In cases of acute intoxications with lead, it causes death up to $100 \%$ of animals (Burki, 2012; Orisakwe et al., 2017).

According to the results of research (Hiatt, 2007), cadmium is also to a high extent introduced into the organism of animals through the gastro- 
intestinal tract. Waalkes (2000) and Djukić-Ćosić et al. (2008) revealed that ingress of excessive amounts of cadmium blocks the work of enzymes that are important to the organism, causes damages to the liver, kidneys, and the pancreas. The greatest accumulation of cadmium was seen in the kidneys ( $30-60 \%$ of the total amount), the liver (20-25\%), as well as in the pancreas, spleen, tubular bones (Gil'denskiol'd et al., 1992). Increased content of cadmium in fodder crops $(2.5-5.0 \mathrm{mg} / \mathrm{kg})$ is also noted in the areas of ore explorations of zinc and lead, schist deposits, zinc-smelters (Kozak \& Brygadyrenko, 2018). Diets for cattle that contain $5-30 \mathrm{mg} / \mathrm{kg}$ of $\mathrm{Cd}$ decrease the productivity, $\geq 30 \mathrm{mg} / \mathrm{kg}$ causes health issues, more than $40 \mathrm{mg} / \mathrm{kg}$ - animals suffer from parakeratosis (Mc Dowell, 1992). Intake of polluted food, cadmium-polluted water lead to ingress of this element into the organism, where it is absorbed by the cells of the intestine and transported by the blood stream to the liver (Patra, 2006), having a negative impact on the health of animals (Stanevičienè et al., 2008).

A biological peculiarity of young animals is ability for intensive growth, development and efficient use of nutritious substances of the muscular tissues in the conditions of organization of detailed feeding (Ibatullin et al., 2016). Therefore, production of high-quality beef must be based on a stable, ecologically pure, biologically substantial diet for young cattle from birth to slaughter, depending on age, breed, and live mass of the animals.

According to data Bohdanov et al. (1986), the commonest type of diet for young cattle on the farms of Ukraine in winter is silage and silageconcentrate. At the same time, chemical composition, nutritive value of silage fodders change depending on natural-climatic conditions, phases of vegetation, technologies of cultivation, preparation, maintenance and preparation of plants for feeding (Savchenko, 2008). Use of silage as the main food in the diets of cattle causes deficiency in digestible protein, sugar, phosphorus, and its carotene is only partly digested in the organism, leading to decrease in the intensity of growth and development of young cattle that are being fattened. The research (Savchenko, 2008) indicates that with intake of root vegetables combined with maize silage in the content of diets during intense fattening of bulls, the average increment of live weight was $200 \mathrm{~g}$ greater compared with the increments in young animals that only received maize silage. The results of our studies revealed that the main pollutants of meat and the liver of animals in the conditions of the Polesia region are roughages prepared by natural drying and silage.

After the experiments, we compared total amounts of heavy metals introduced to the organism of the bulls with the fodders, their content in the longissimus, liver and noted the following patterns of their accumulation. First of all, there occurs uneven digestion of certain elements in the organism of animals. Secondly, their major amount is not deposited in the muscular tissue in the organs, and is removed from the organism. Therefore, in the conditions with high anthropogenic load, to reduce the accumulation of harmful substances in the organism of animals and obtain high-quality products of livestock, scientifically substantiated systems of feeding should be used, balanced according to detailed parameters of nutritive value. In the conditions of deficiencies of protein, easy digestible carbohydrates, mineral elements in the diets, the accumulation of ${ }^{137} \mathrm{Cs}$ and heavy metals in meat and young animals significantly increases, compared with substantial feeding. Regulated protein and carbohydrate nutrition weaken toxic action of harmful substances, decreases ingresses of ${ }^{137} \mathrm{Cs}$ and heavy metals from the gastro-intestinal tract into the blood circulatory system and increases their removal from the organism (Howard et al., 1989; Raikwar et al., 2008).

We consider that the results of our studies will help experts to understand the biological system of internal action of ${ }^{137} \mathrm{Cs}, \mathrm{Pb}, \mathrm{Cd}$ when feeding bulls with silage-concentrate-root vegetable and silage-concentratehay diets in the zone of radioactive contamination in order to organize biologically substantial feeding and production of safe food products.

\section{Conclusions}

Contamination of animal products with radio caesium and heavy metals is a significant way in which they impact on the organism of humans through the food chain. During the production of beef in the Ukrainian Polesia, to reduce ingress of radionuclides and heavy metals into meat, an important factor is diet, determined first of all by the level of contamination of the food, type of diet and balance of diets according to detailed parameters.

Feeding young bulls with various types of diets decreased the specific activity of ${ }^{137} \mathrm{Cs}$ in the longissimus by $8.7-20.1 \%$ compared with the parameters of the young animals of the control group. Transfer coefficients of ${ }^{137} \mathrm{Cs}$ from the fodders into beef and the liver of animals of the II and III groups, as compared with the I group, were 0.35-0.47 and 0.04 $0.15 \%$ lower respectively. Accumulation of $\mathrm{Pb}$ in the longissimus of the young bulls of all the studied groups was much below the MAL. Concentration of this metal in beef of young animals of the II group was $36.2 \%$ lower, whereas in the III group, this parameter was $6.7 \%$ higher compared with the analogues of the I group. Transfer coefficients of $\mathrm{Pb}$ from the fodders into the longissimus was $0.27-0.48 \%$ lower in the II group and $1.39-4.81 \%$ lower for the transfer into the liver of animals of the III group. Concentration of $\mathrm{Cd}$ in the longissimus of the fattened animals of all the groups was 1.7-5.1 times above the MAL. At the same time, use of silage-concentrate-root vegetable and silage-concentrate-hay types of diet in feeding the bulls led to $34.1-66.7 \%$ lower $\mathrm{Cd}$ accumulation in the muscular tissue and 15.3-46.6\% lower its concentration in the liver compared with silage-concentrate diets.

Further studies require systematic monitoring of radioactive elements, heavy metals in the trophic chain of soil - fodders - animals - products humans and development of a complex of ecological measures to reduce the introduction of pollutants into fodders and their negative impact on the organism of animals and for production of safe food products.

\section{References}

Beresford, N. A., \& Howard, B. J. (2011). Review of radionuclide transfer to farm animals and potential countermeasures relevant to emissions in Fukushima. Integrated Environment Assessment and Management, 7, 382-384.

Bohdanov, H. O., Karavashchenko, V. F., \& Zvyeryev, O. I. (1986). Dovidnyk po hodivli sil's'kohospodars'kykh tvaryn [Handbook for feeding farm animals]. Kyiv, Urozhay (in Ukrainian).

Burki, T. K. (2012). Nigeria's lead poisoning crisis could leave a long legacy. Lancet, 379(9818), 792.

Djukić-Ćosić, D., Jovanović, M. C., Blut, Z. P., Ninković, M., Maličevic, Z., \& Matović, V. (2008). Relation between lipid peroxidation and iron concentration in mouse liver after acute and subacute cadmium intoxication. Joumal of Trace Elements in Medicine and Biology, 22(1), 66-72.

El-Sharaky, A. S., Newiry, A. A., Badreldreen, M. M., Ewada, S. M., \& Sheweita, S. A. (2007). Protective role of selenium against renal toxicity induced by cadmium in rats. Toxicology, 235, 185-193.

Foster, W. G. (1992). Reproductive toxicity of chronic lead exposure in the female cynomolgus monkey. Reproductive Toxicology, 6, 123-131.

Gil'denskiol'd, R. S., Novikov, Y. V., \& Khamidulin, R. S. (1992). Tyazhelyye metally v okruzhayushchey srede i ikh vliyaniye na organism [Heavy metals in the environment and their effect on the body]. Gigiyena i Sanitariya, 5-6, 6-9 (in Ukrainian).

Hashimoto, K., Tanoi, K., Sakurai, K., Hashimoto, T., Nogawa, N., Higaki, C., Kosaka, N., Takahashi, T., Enomoto, J., Onoyama, I., Li, J., Manabe, N., \& Nakanishi, T. (2011). Measurement of radioactivity of cow's milk supplied with pasture grown in Ibaraki Prefecture after the accident at the Fukushima Nuclear Power Plant. Radioisotopes, 60, 335-338.

Hatch, M., Ron, E., Bouville, A., Zablotska, L., \& Howe, G. (2005). The Chemobyl disaster: Cancer following the accident at the Chernobyl nuclear power plant. Epidemiologic Reviews, 27(1), 56-66.

Hayama, S., Nakiri, S., Nakanishi, S., Ishii, N., Uno, T., Kato, T., \& Konno, F. (2013). Concentration of radiocesium in the wild Japanese monkey (Macaca fuscata) over the first 15 mounths after the Fucushima Daichi Nuclear Disaster. PloS One, 8,68530

Hiatt, V., \& Huff, J. E. (2007). The environmental impact of cadmium: An overview. International Journal of Environmental Studies, 7, 277-285.

Howard, B. J., Beresford, N. A., \& Voigt, G. (2001). Countermeasures for animal products: A review of effectiveness and potential usefulness after an accident Journal of Environmental Radioactivity, 56, 115-137.

Ibatullin, I. I., Bashchenko, M. I., Zhukors'kyy, O. M., \& Tsvihun, A. T. (2016). Dovidnyk z povnotsinnoyi hodivli sil's'kohospodars'kykh tvaryn [Handbook of complete feeding of farm animals]. Ahrarna Nauka, Kyiv (in Ukrainian).

Jadhav, S. H., Sarkar, S. N., Patil, R. D., \& Tripathi, H. C. (2007). Effects of subchronic exposure via drinking water to a mixture of eight water contaminating metals: A biochemical and histopathological study in male rats. Environmental Contamination and Toxicology, 53(4), 667-677. 
Kan, C. A., \& Meijer, G. A. L. (2007). The risk of contamination of food with toxic substances present in animal feed. Animal Feed Science and Technology, 133, 84-108.

Kozak, V. M., \& Brygadyrenko, V. V. (2018). Impact of cadmium and lead on Megaphyllum kievense (Diplopoda, Julidae) in a laboratory experiment. Biosystems Diversity, 26(2), 128-131.

McDowell, L. R. (1992). Cadmium. In: McDowell, L. R. (Ed.). Minerals in animal and human nutrition. Academic Press, London. Pp. 359-361.

Muller, M., \& Anke, M. (1994). Distribution of cadmium in the food chain (soil plant - human) of a cadmium exposed area and the health risks of the general population. Science of the Total Environment, 156(2), 151-158.

Newairy, A. A., El-Sharaky, A. S., Baldreldeen, M. M., Eweda, S. M., \& Sheweita, S. A. (2007). The hepatoprotective effects of selenium against cadmium toxicity in rats. Toxicology, 242, 23-30.

Orisakwe, O. E., Oladipo, O. O., Ajaezi, G. C., \& Udowelle, N. A. (2017). Horizontal and vertical distribution of heavy metals in farm produce and livestock around lead-contaminated goldmine in Dareta and Abare, Zamfara State, Northern Nigeria. Journal of Environmental and Public Health, 2017, 3506949.

Patra, R. C., Rautray, A. K., \& Swarup, D. (2011). Oxidative stress in lead and cadmium toxicity and its amelioration. Veteterinary Medicine International, 2011, 457327.

Patra, R. C., Swarup, D., Sharma, M. C., \& Naresh, R. (2006). Trace mineral profile in blood and hair from cattle environmentally exposed to lead and cadmium around different industrial units. Journal of Veteterinary Medicine Series A, 53(10), 511-517.

Patrick, L. (2006). Lead toxicity. Part II. The role of free radical damage and the use of antioxidants in the pathology and treatment of lead toxicity. Alternative Medicine Review, 11(2), 114.

Pichtel, J., Kuroiwa, K., \& Sawyerr, H. T. (2000). Distribution of Pb, Cd and Ba in soils and plants of two contaminated sites. Environmental Pollution, 110(1), 171-178.

Raikwar, M. K., Kumar, P., Singh, M., \& Singh, A. (2008). Toxic effect of heavy metals in livestock health. Veterinary World, 1(1), 28-30.
Rodríguez, E. M., Bigi, R., Medesani, D. A., Stella, V. S., Greco, L. S. L., Moreno, P. A. R., Monserrat, J. M., Pellerano, G. N., \& Ansaldo, M. (2001). Acute and chronic effects of cadmium on blood homeostasis of an estuarine crab, Chasmagnathus granulata, and the modifying effect of salinity. Journal of Medical and Biological Research, 34(4), 509-518.

Salt, C. A., Mayes, R. W., \& Elston, D. A. (1992). Effects of season, grazing intensity and diet composition on the radiocaesium intake by sheep on re-seeded hill pasture. Journal of Applied Ecology, 29(2), 378-387.

Savchenko, Y. I. (2008). Optymizatsiya vuhlevodnoho zhyvlennya velykoyi rohatoyi khudoby [Optimization of carbohydrate nutrition of cattle]. Ahrarna Nauka, Kyiv (in Ukrainian)

Stanevičienė, I., Sadauskienė, I., Lesauuskaite, V., Ivanovienė, L., Kašauskas, A., \& Ivanov, L. (2008). Subacute effects of cadmium and zinc ions on protein synthesis and cell death in mouse liver. Medicina (Kaunas), 44(2), 131-136.

Steinhauser, G. (2017). Monitoring and radioecological characteristics of radiocesium in Japanese beef after the Fukushima nuclear accident. Joumal of Radioanalytical and Nuclear Chemistry, 311(2), 1367-1373.

Summerling, T. J. (1984). In-vivo estimates for the uptake of caesium-137 by cattle granzig contaminated pasture around the Esk and Irt Estuaries, Cumbria, U.K. Science of the Total Environment, 22(1), 39-50.

Swarup, D., Naresh, R., Varshney, V. P., Balagangatharathilagar, M., Humar, P., Nandi, D., \& Patra, R. C. (2007). Changes in plasma hormones profile and liver function in cows naturally exposed to lead and cadmium around different industrial areas. Research in Veterinary Science, 82(1), 16-21.

Uetani, M., Kobayashi, E., Suwazono, Y., Okubo, Y., Honda, R., Kido, T., \& Nogawa, K. (2005). Selenium, cadmium, zinc, copper, and iron concentrations in heart and aorta of patients exposed to environmental cadmium. Bulletin of Environmental Contamination and Toxicology, 75(2), 246-250.

Waalkes, M. P. (2000). Cadmium carcinogenesis in review. Joumal of Inorganic Biochemistry, 79, 241-244.

Yu, H., Wang, J., Fang, W., Yuan, J., \& Yang, Z. (2006). Cadmium accumulation in different rice cultivars and screening for pollution-safe cultivars of rice. Science of the Total Environment, 370, 302-309. 